\title{
Documentation and Evaluation of Traditional Meat Products of North Malabar
}

\author{
Renuka Nayar ${ }^{1}$, Kavitha Rajagopal ${ }^{1}$, Solomon Rajkumar $^{1 *}$ and Magna Thomas $^{2}$
}

${ }^{1}$ Department of Livestock Products Technology, College of Veterinary and Animal Sciences, Kerala Veterinary and Animal Sciences University, Pookode, Lakkidi PO- 673576, Wayanad, Kerala, India

${ }^{2}$ Department of Dairy Science, College of Veterinary and Animal Sciences, Kerala Veterinary and Animal Sciences University, Pookode, Lakkidi PO- 673576, Wayanad, Kerala, India

*Corresponding author

\section{A B S T R A C T}

Keywords

Beef, Chicken, Meat protein, Proximate composition, Traditional foods

Article Info

\section{Accepted:}

12 December 2020 Available Online: 10 January 2021
Traditional meat products with their unique sensory attributes have known to hold tremendous mass appeal, usually with high nutritional value. Kerala cuisine is a unique blend of indigenous and exotic dishes adapted to local culinary culture. Ethnic meat products from the Northern Malabar region have been described in several popular culinary books. However, there has been limited scientific documentation of these products and the estimation of their nutritive value. A field survey was conducted in four districts of North Malabar region of Kerala viz., Kasaragod, Kannur, Kozhikode and Wayanad for creating a database of the major and popular ethnic meat products of the region. A total of 24ethnic meat products of the North Malabar region of Kerala have been cataloged and the proximate composition of five selected products has been described in this study.

\section{Introduction}

Globally the livestock sector is highly dynamic and in developing countries, there is a rapid increase in the demand for livestock products (Thornton, 2010). The traditions and culture influence meat consumption to a great extent in India(Devi et al., 2014). Traditional meat products are high sensory quality foods, usually with high nutritional value, produced on a small scale, using ingredients and procedures from ancient times (Laranjo et al., 2017). All over the world, different processes are used to preserve meat and the traditional knowledge of people living in different regions gave rise to a great diversity of meat products according to their traditions and historic use. These traditional processes, their 
particularities, and their effect on the quality and safety of meat products are important research topics. However, lesser efforts are being laid to convert this actual knowledge to engaging knowledge.

Kerala is the southernmost state on India's tropical Malabar Coast of the Arabian Sea. Kerala has its food heritage and the cuisine of the land is linked to the history, geography, demography, and culture of the land. For over 2000 years, Kerala had been visited by traders from Greece, Rome, Mediterranean, European and Arab countries, mainly for the spices from Malabar. As a result of the trade relationship and cultural influence, Kerala cuisine is a unique blend of indigenous and exotic dishes adapted to local culinary culture. The styles of cooking as well as recipes of the erstwhile Travancore and Kochi, respectively in the south and central parts of Kerala and Malabar in the north Kerala vary widely. Dishes from the Travancore region are influenced by colonial cuisine adapted by the Syrian Christians. Malabar area especially the northern part of Malabar had been influenced by Arabs and has a variety of non-vegetarian dishes probably of Arab origin propagated by Muslims. Besides their historic and cultural influences, Islam and Christianity contributed distinctive styles to Kerala cuisine.

While the temporal changes in meat production has witnessed a steady growth, the market share of processed meat products in India accounts for hardly one percent. This could be attributed to the lesser regard by the population of the region to recognized processed products especially of the western countries, like ham, patties or sausages. However, traditional meat products with their unique sensory attributes have known to hold tremendous mass appeal (Anjaneyulu et al., 2008).

For the conservation of knowledge on the ethnic meat products in Kerala as well for easy accessibility of this knowledge base, a systematic mapping and documentation is essential. There are traditional products which are popular either in a group of people or to a limited geographical region. There is wide acceptance for these products among other communities in these areas, especially during religious festivals. These delicacies which presently are limited in use in the local areas have to be popularized in other parts of Kerala as well as outside the state. Ethnic meat products from the Northern Malabar region have been described in several popular culinary books. However, there has been limited scientific documentation of these products and the estimation of their nutritive value. Considering the diversities of the ethnic meat products, several popular products have been identified in this study to document the uniqueness in their ingredients and cooking method, the pattern of consumption of these dishes, and their proximate composition.

\section{Materials and Methods}

A field survey was conducted in four districts of North Malabar region of Kerala viz., Kasaragod, Kannur, Kozhikode and Wayanad for creating a database of the major and popular ethnic meat products of the region.

Information regarding the products qualifying for the study was gathered from local caterers/cooks, bakers, and housewives. These respondents were interacted with and the information was documented based on direct observation.

Processing of the selected products was standardized at the Department of Livestock Products Technology, College of Veterinary and Animal Sciences, Pookode, Wayanad concerning the formulation, processing, and storage. A total of five popular products were analyzed for the proximate composition as per AOAC(Cunniff, 1995). 


\section{Results and Discussion}

North Malabar population has their ethnic meat products that are prepared according to the knowledge handed down through generations. A total of 24ethnic meat products of the North Malabar region of Kerala have been cataloged in Table 1. The proximate composition of five selected products have been described in Table 2. Photographs of selected meat products are represented in the figures (1-8).

\section{Seasoned and curried meat products}

Curried meat products are spicy Indian traditional food products prepared with meat, vegetables, spices, and condiments (Girish et al., 2018). Varuthaarachakozhi curry and Kozhivarattiyathu are the most commonly made curry products of Malabar which are cooked in water as a medium with grated coconut, seasonings and spices whereas, in curries like chicken stew, mutton pachamallythenga pal, coconut milk is added to get desired consistency to the gravy. Meat curry is usually served with steamed rice and also with traditional rice and wheat preparations like vellappam, vattayappam, idiyappam/noolappam, pathiri, puttuchappati, paratha etc. However, Kozhikadambu/ kozhipidi or Kakkaoroti/Kunjipathiri is the chicken/meat curry served with rice dumplings. Similarly, Eenthupidi is a chicken curry served with queen palm sago (Cycas circinalis) dumplings.

The ideal ratio of meat to gravy ratio for the curried product should be 60:40 (Anjaneyulu et al., 2008). Chilling or freezing is the most common method of storing meat curries in households. Chicken curry made from deboned broiler chunks had a shelf life of six months during freezer storage without marked changes in the quality (Modi et al., 2006). Further, with the use of hurdle technology, the storage life of mutton and chicken curry could be extended (Das and Radhakrishna, 2001; Das and Jayaraman, 2003). Thermal processing in retort pouches to extend shelf life has been successfully documented for different meat products by many researchers; like chicken meat (Lyon and Klose, 1981), beef stew (Cremer and Pizzimenti, 1992), beef curries(Koo et al., 1993), Chettinad chicken curry (Rajkumar et al., 2010) and pork curry (Girish et al., 2018).

Kerala is popular for its wide range of tropical spices and herbs. Traditionally, meats are seasoned with salt, spices, and herbs to preserve and to enhance the organoleptic properties. Kozhivaraval is chicken cooked with grated coconut, condiments, and spices without gravy. Erachisukka is beef cooked with grated coconut, condiments, and spices in earthen pot without oil. Kozhinirachathu is whole spring chicken stuffed with spices and hard-boiled eggs deep-fried or roasted. Aattinkalchuttathu and Aattinthala are seasoned goat legs and head, respectively.

The antimicrobial and antioxidant effects of different spices on rista, a traditional meat product from Jammu and Kashmir has been evaluated during ambient and refrigerated $\left(4 \pm 1^{\circ} \mathrm{C}\right)$ conditions for 25 days of storage and demonstrated that clove spice used in the rista is highly effective against microbial growth and lipid oxidation and show greater potential as a natural antioxidant and sensory attributes in the product during storage (Mir et al., 2017). Similarly, the antimicrobial activity of six Indian spice extracts which have been traditionally used in folk medicine has been evaluated and tested against three potent foodborne pathogens, namely Escherichia coli, Staphylococcus aureus, and Bacillus cereus and the results showed that the extracts of clove, cinnamon and mustard had good inhibitory action at $1 \%$ concentration, while garlic showed medium activity. At 3\% concentration, a complete bactericidal effect was achieved. Ginger and mint showed 
negligible antibacterial activity against these pathogens at the same concentration (Sofia et al., 2007).

One of the distinct meat preparations of the Malabar region Nadankozhimarunnu curry was standardized in the present study and the results of the proximate analysis are given in Table 3. This product is revered for its medicinal value and is served in the monsoon months. Ayurvedic ingredients like ajwan or carom seeds (Trachyspermum ammi), coriander, cumin seeds, black pepper, ground gooseberry, ginger-garlic paste, lemon juice and "inthuppu" (potassium chloride) are used in the preparation. This medicinal masala mix is applied inside as well as on the outside of the whole chicken and wrapped in plantain leaves, tied and covered with clay, and cooked in the traditional stove with coconut husk as fuel.

The chicken is slowly cooked in its fat for one and a half hours and the warmth will be maintained for almost five hours. This product is dry heat cooked and has low moisture content and keeps well for 2-3 days. This is believed to be beneficial for stimulating the immune system and health during the monsoon months when most of the ayurvedic treatments are done.

\section{Meat cooked with whole cereals}

Biryani, seasoned rice cooked with meat is a very popular meat product throughout India. "Thalasserybiryani" or "Malabar biryani" is the signature dish of the north Malabar region and has high consumer appeal and is served during marriages and other functions as well as during festivals especially by the Muslim community. Generally, this product is cooked and consumed fresh except in households where the surplus product is chiller stored for 1-2 days. Previous researchers developed dehydrated pulav with a shelf life of about six months at $37^{\circ} \mathrm{C}$ (Mathur et al., 1973). Similarly, mutton keema biryani was evaluated for its shelf stability in retort pouches under room temperature for two months and noted that on storage, moisture, water activity, protein and ash contents of the product did not show any significant change but the total fat content was found to decrease (Lavanya et al., 2016). Chicken pulav in pouches of polypropylene film and paper-foilpolyethylene laminate had a shelf-life of 8-12 months at ambient storage and 14-18 months at chill temperatures with acceptable physiochemical, microbiological and sensory attributes (Das and Jayaraman, 2003).

Table.1 Proximate composition $(\% \pm \mathrm{SE})$ of selected ethnic meat of Malabar region of Kerala

\begin{tabular}{|r|l|l|l|l|l|l|}
\hline $\begin{array}{l}\text { S. } \\
\text { No. }\end{array}$ & Product & Moisture & Fat & Protein & Ash & Carbohydrate \\
\hline 1. & Erachipathiri & $62.62 \pm 0.48$ & $2.21 \pm 0.06$ & $3.12 \pm 0.08$ & $1.50 \pm 0.09$ & $30.18 \pm 0.65$ \\
\hline 2. & Kozhiada & $65.63 \pm 0.58$ & $4.57 \pm 0.20$ & $3.56 \pm 0.16$ & $1.37 \pm 0.10$ & $24.86 \pm 0.53$ \\
\hline 3. & Eenthupidi & $37.40 \pm 0.44$ & $18.60 \pm 0.64$ & $3.35 \pm 0.15$ & $2.31 \pm 0.16$ & $38.34 \pm 0.84$ \\
\hline 4. & Marunnukozhi & $49.47 \pm 1.47$ & $1.34 \pm 0.13$ & $4.27 \pm 0.19$ & $3.98 \pm 0.27$ & $40.95 \pm 1.11$ \\
\hline 5. & Alissa & $72.50 \pm 0.77$ & $3.47 \pm 0.22$ & $1.55 \pm 0.10$ & $0.88 \pm 0.08$ & $21.60 \pm 0.83$ \\
\hline
\end{tabular}


Table.2 Description of popular traditional meat products of North Malabar region of Kerala

\begin{tabular}{|c|c|c|c|}
\hline S. No & Ethnic name & Description & Method of cooking \\
\hline 1. & $\begin{array}{l}\text { Chorapathiri/erachipathiri } \\
\text { /Attipathiri }^{\# \wedge}{ }_{\wedge}\end{array}$ & Meat stuffed layered rice pancakes & Steaming \\
\hline 2. & Athishayapathiri & Meat stuffed layered wheat pancakes & Steaming \\
\hline 3. & Chatti pathiri (spicy) $)^{\# \$_{\wedge}}$ & Meat stuffed flatbread & $\begin{array}{l}\text { Shallow fat frying along with } \\
\text { application of cinders on the lid }\end{array}$ \\
\hline 4. & Cutlet $^{\$}$ & $\begin{array}{l}\text { Patty of spiced minced meat with } \\
\text { potato as binder and covered with } \\
\text { breadcrumbs }\end{array}$ & Deep fat frying \\
\hline 5. & Samosa ${ }^{\$}$ & $\begin{array}{l}\text { Triangular pastry case containing } \\
\text { spiced meat }\end{array}$ & Deep fat frying \\
\hline 6. & $\begin{array}{l}\text { Erachiada/erachipathal/er } \\
\text { achi petti }\end{array}$ & $\begin{array}{l}\text { Crescent shaped pastry case } \\
\text { containing spiced meat }\end{array}$ & $\begin{array}{l}\text { Steaming } \\
\text { Deep fat frying }\end{array}$ \\
\hline 7. & Chicken roll $^{\$}$ & $\begin{array}{l}\text { Cylindrical savory containing spiced } \\
\text { meat }\end{array}$ & Deep fat frying \\
\hline 8. & Kakkaoroti/Kunjipathiri^ ${ }^{\wedge}$ & Rice dumplings in meat curry & Steaming \\
\hline 9. & Erachi bonda $\$$ & $\begin{array}{l}\text { Savory balls of minced meat and } \\
\text { potato, battered and fried }\end{array}$ & Deep fat frying \\
\hline 10. & Erachiidli $^{\$}$ & Spiced wheat dumplings with meat & Steaming \\
\hline 11. & Alissa ${ }^{\wedge}$ & $\begin{array}{l}\text { Wheat porridge cooked with meat } \\
\text { and spices }\end{array}$ & Pressure cooking/stewing \\
\hline 12. & Biriyani^ $^{\wedge}$ & Seasoned rice cooked with meat & Steaming \\
\hline 13. & $\begin{array}{l}\text { Mutton pachamallythenga } \\
\text { pal curry^}\end{array}$ & Curried mutton in coconut milk. & Braising \\
\hline 14. & $\begin{array}{l}\text { Varutha arachakozhi } \\
\text { curry^}^{\wedge}\end{array}$ & $\begin{array}{l}\text { Curried chicken is sautéed and } \\
\text { ground coconut }\end{array}$ & Braising \\
\hline 15. & Kozhi varattiyathu^ & Curried Chicken in coconut milk. & Braising \\
\hline 16. & Chicken stew $^{\# \wedge} \wedge$ & Chicken stewed in coconut milk & Stewing \\
\hline 17. & Kozhi nirachathu^ & $\begin{array}{l}\text { Whole spring chicken stuffed with } \\
\text { spices and hard-boiled eggs }\end{array}$ & Deep fat frying/roasting \\
\hline 18. & Aattin kalchuttathu^ & Seasoned goat leg & Roasting \\
\hline 19. & Aattinthala^ & Seasoned goat head & Simmering/braising \\
\hline 20. & Kozhi kadambu/kozhipidi^ & Rice dumplings in chicken curry & Steaming \\
\hline 21. & Eenthupidi^ $^{\wedge}$ & $\begin{array}{l}\text { Queen palm sagodumplings in } \\
\text { chicken curry }\end{array}$ & Steaming \\
\hline 22. & Kozhi varaval^ & $\begin{array}{l}\text { Chicken cooked with grated coconut, } \\
\text { condiments and spices without gravy }\end{array}$ & Braising \\
\hline 23. & Erachi sukka^ & $\begin{array}{l}\text { Beef cooked with grated coconut, } \\
\text { condiments and spices in earthen pot } \\
\text { without oil }\end{array}$ & Simmering \\
\hline 24. & 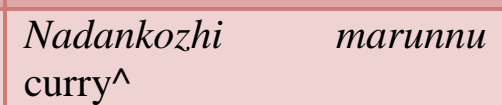 & $\begin{array}{l}\text { Country chicken cooked with } \\
\text { ayurvedic (medicinal) ingredients }\end{array}$ & $\begin{array}{l}\text { Dry heat cooked in traditional } \\
\text { stove with coconut husk as fuel }\end{array}$ \\
\hline
\end{tabular}


Fig. 1 Erachipathiri

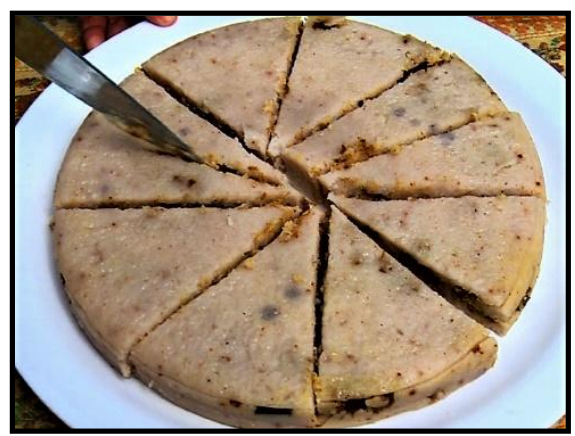

Fig.1

Fig. 3- Samosa

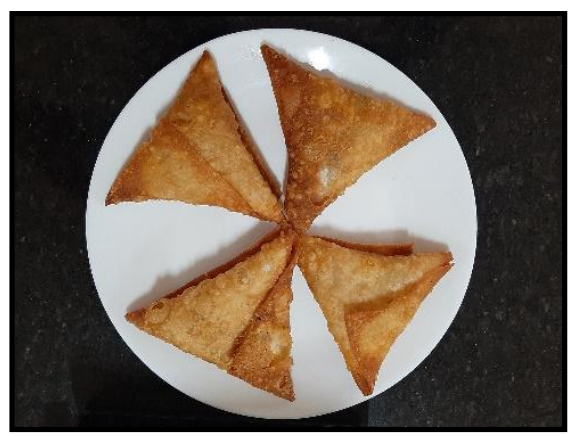

Fig.3

Fig. 5- Chicken roll

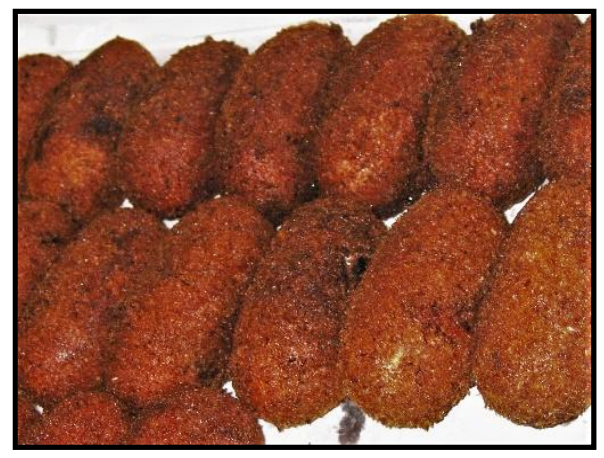

Fig.5
Fig.2 Cutlet

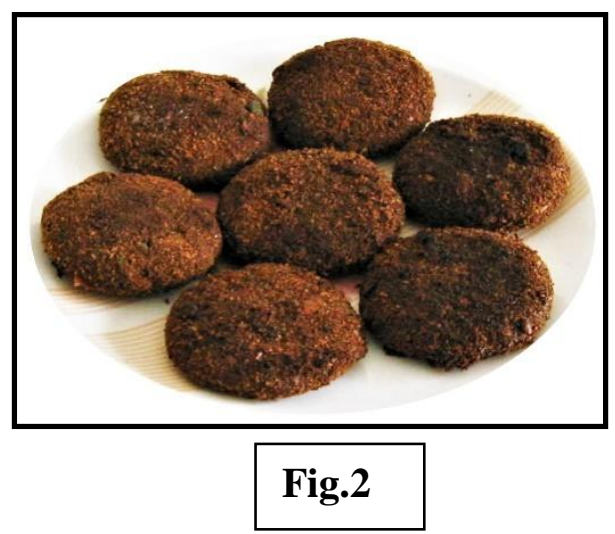

Fig. 4- Erachiada

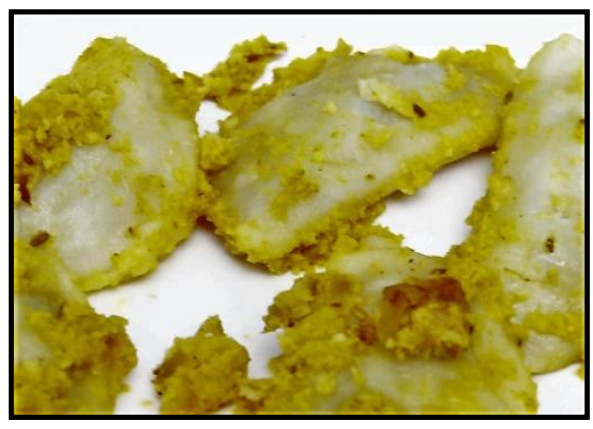

Fig.4

Fig. 6- Alissa

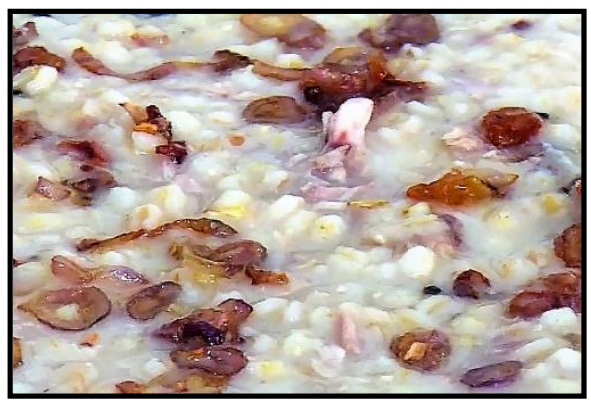

Fig.6 
Fig. 7- Eenthupidi

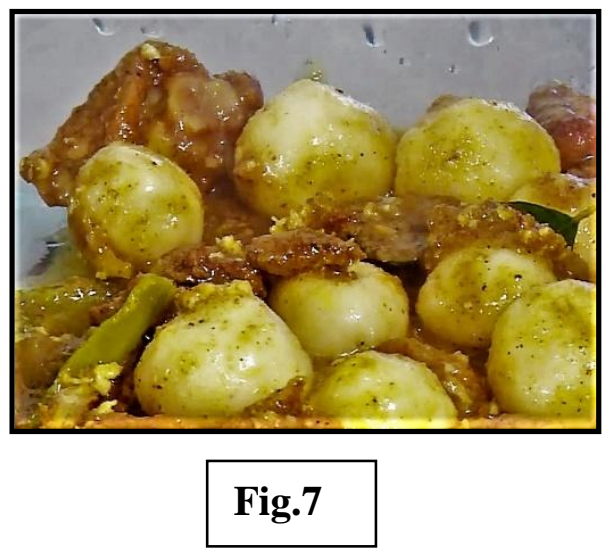

Alissa is a porridge cooked with whole wheat, meat, and spices similar to Harrisa of Jammu and Kashmir and Hyderabadi Haleem. These products have a pasty consistency and rich spicy flavor. These products are commonly consumed during the holy month of Id-ulmilad/ Ramadan. The shelf life of goat meat Haleem made with a meat to extender ratio of 3:1 with wheat as an extender has been studied. The ratio was found to be optimum to prepare quality Haleem which could be stored in a freezer $\left(-18 \pm 1^{\circ} \mathrm{C}\right)$ safely up to 30 days(Rasheed et al., 2007).

During the present study,the proximate composition of the Alissa revealed moisture as $72.50 \% \pm 0.77$; fat as $3.47 \% \pm 0.22$; protein as $1.55 \% \pm 0.10$ and ash as $0.88 \% \pm 0.08$. Studies on similar product Harrisa prepared using mutton meat was attempted and reported moisture as $74.7 \% \pm 0.15$; fat as $10.5 \% \pm 0.35$, protein as $12.1 \% \pm 0.37$ and ash as $2.1 \% \pm 0.18$ (Bhat and Pathak 2012) Similarly, the proximate composition of chicken meat-based Hyderabadi Haleem has been reported as moisture $79.1 \%$; protein $6.5 \%$, and fat $7.0 \%$ (Muthukumar et al., 2015).

\section{Enrobed and stuffed meat products}

Enrobing with edible coatings has been reported to improve the quality and extended
Fig. 8- Nadankozhi marunnu curry

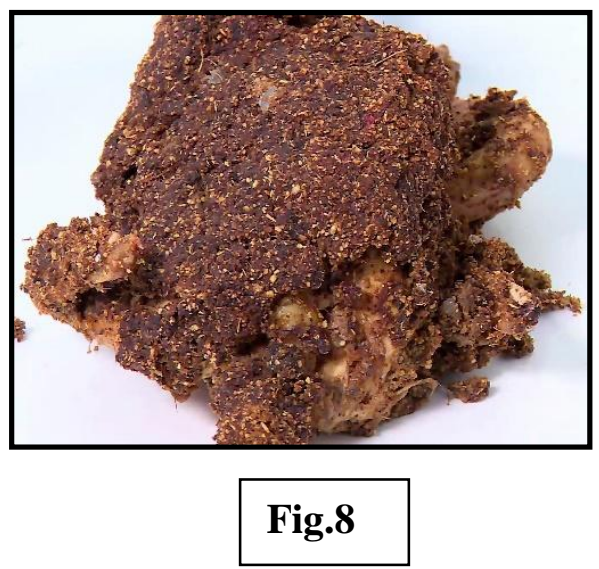

shelf life of fresh frozen and fabricated foods (Biswas et al., 2004; Chidanandaiah et al., 2005; Mendiratta et al., 2005). Enrobed and stuffed meat products are popular in North Malabar and are often consumed as snacks. They may be fried or steam cooked. Erachiada/erachipathal/erachi petti is a snack which is either steam-cooked or deepfried. It is prepared from seasoned and spiced chicken or beef mince stuffed in dough made of either fine rice flour or refined wheat flour. Adas prepared using rice dough are usually steam cooked and those prepared from refined wheat flour dough are deep-fried. They are usually semicircular and molded by hand or by small molds. For greater shelf life, onion and green chilies are not added in the meat mix and the mix is heated on low flame to reduce the moisture content. Kozhiadais an enrobed and steamed product stuffed with spiced and minced chicken similar to chicken Momo. The proximate composition of the Kozhiada revealed moisture as $65.63 \% \pm 0.58$; fat as $4.57 \% \pm 0.20$; protein as $3.56 \% \pm 0.16$ and ash as $1.37 \% \pm 0.10$. The fat and protein content of the Kozhiada is significantly higher while compared to reported moisture $(62.67 \% \pm 0.30) ;$ fat $(10.66 \% \pm 0.01)$ and protein $(17.94 \% \pm 0.20)$ of similar product chicken Momo (Rathod, 2019).

Erachi bonda is a savory ball of minced meat and potato, battered and fried. 
Chorapathiri, erachipathiri, Attipathiri are layered rice pancakes stuffed with seasoned and spiced meat. Similarly, Athishayapathiri is layered wheat pancakes stuffed with meat. All the above products are steam cooked, whereas Chatti pathiri is ameat-stuffed flatbread cooked by shallow fat frying along with the application of cinders on the lid. Meat samosa especially chicken samosa is another popular snack that is seasoned and spiced meat filled in pastry sheets made of refined wheat flour and deep-fried. Unlike the North Indian samosas, these samosas are triangular shaped and thinner. Previous researchers have evaluated the quality of meat samosa stuffed by incorporating different binders (Keshri et al., 1988) and extenders Meat stuff extended with $10 \%$ potato mash and $5 \%$ green peas was rated to be highly acceptable(Sharma et al., 1988) Samosa can also be prepared by effectively utilizing the chicken meat from Chicken frames (Chauhan et al., 2003).

Chicken/meat cutlet is the most popular snack product available in restaurants and bakeries all over the Malabar region. Cutlets are flat croquette of flour, pulse, nuts, potato, condiments, spices and often coated with bread rusk crumbs and are considered as one of the most popular snack-based products(Singh et al., 2014). In Kerala cooked and minced chicken, as well as beef, are used for cutlet preparation, and potato is used as binder. Ready-to-fry cutlets after enrobing can be freezer stored. Novel chicken cutlets were prepared to replace the potato with elephant foot yam (Amorphophallus paeoniifolius) and observed that the products had a higher level of phenolic antioxidants, higher DPPH radical scavenging ability and better nutritive value than traditional cutlets (Kurian et al., 2016). Erachiidli is a steam cooked wheat dumpling with spiced and seasoned meat added. The effect of various cooking methods for the preparation of chicken meat cutlets was assessed and reported that oven cooking followed by shallow frying was found optimum for the preparation of chicken cutlets(Singh et al., 2015). Similarly, effect of clove bud oleoresin and turmeric oleoresin on the quality of chicken cutlet incorporated with elephant foot yam (Amorphophallus paeoniifolius) and stored in a freezer $\left(-18 \pm 2^{\circ} \mathrm{C}\right)$ was studied and reported that clove bud oleoresin and turmeric oleoresin at $0.5 \%$ level can effectively be incorporated in chicken cutlets for increasing freezer shelf life without affecting the sensory attributes (Paulose et al., 2018)

So concluded currently, worldwide, in an attempt to bring in food sovereignty, indigenous communities seek to revive their healthy cultural nutrition practices in ways that honor their traditions and world views. Building well-being based on local food systems depends on understanding and sharing the local food resources and traditional ways of growing, harvesting, preserving and preparing the foods, and using this information to build health-promotion activities. Similar attempts concerning traditional meat products and heritage foods have been undertaken by many researchers in India also. The accessibility to traditional cuisine has been influenced by changes in landscapes as well as immigration to various places in search of livelihood. The desirability of traditional products is influenced by these factors as evidenced by the high response to various convenient products. In this context, the documentation of these ethnic products is of relevance.

However, with the consumers being more informed and increasingly more demanding, there is a need to satisfy the expectations of consumers, regarding sensory, nutritional aspects, and safety. The major constraints in promoting traditional food products are the lack of standardized technology in 
production, adoption of a batch process which is time-consuming, limited shelf life attributed to the lack of scientific approach in processing as well as non-availability of cold chains ${ }^{4}$. The food safety concerns of traditional foods have to be given due consideration and there is a need for formulation of standards for established ethnic products. Moreover, the knowledge base on process optimization, packaging systems, and storage conditions has to be enhanced with the scientific practices in place to enhance the quality of these products. Adoption of newer technologies like continuous processing systems and thermal processing might help in the distribution of the products to much wider geographical areas and different cultures. This way, it can contribute to the economy of the region by promoting culinary tourism.

The current study helped in creating a database by collecting firsthand information from the home track of the dishes and authentic documentation has been done. The formularies, processing techniques as well as proximate composition have been assessed. However, assessment and assurance of Physico-chemical and microbiological qualities as well as optimum packaging conditions, the shelf life of these products, etc. are some of the attributes to be standardized and validated for consistency and uniformity of the product. This is required for the industrial production of these products. This would help in the large-scale industrial production of the products, which has the potential to generate employment in the sector.

\section{Competing interests}

The authors declare that they have no known competing financial interests or personal relationships that could have appeared to influence the work reported in this paper

\section{Funding}

The present study was conducted with the financial support from "Plan fund" of Government of Kerala, India

\section{Acknowledgements}

The authors would like to thank participating respondents of Kerala for making this study possible. We also acknowledge the technical support given by Dr. Paramesh Venkatesh (ICAR-CCARI, Goa). We gratefully acknowledge the support of officials of Kerala Veterinary and Animal Sciences University, Wayanad, Kerala, India

\section{References}

Anjaneyulu, ASR., Thomas, R., Gadekar, Y.P., Lakshmanan, V., and Mahapatra, C.M. 2008 Indian traditional meat products and their processing, quality, present scenario and future prospects. Indian Food Ind. 27(2):53.

Bhat, Z. F., and Pathak, V. 2012. Quality evaluation of mutton Harrisa during one week refrigerated storage. J Food Sci Technol. 49(5):620-625.

Biswas, A. K., Keshri, R. C., and Bisht, G. S. 2004. Effect of enrobing and antioxidants on quality characteristics of precooked pork patties under chilled and frozen storage conditions. Meat Sci. 66(3):733-741.

Chauhan, G., Kondaiah, N., Anjaneyulu, A. S. R., Mendiratta, SK., and Keshri, RC. 2003. Studies on development of chicken samosa from cooked meat of spent hen frames. Indian $\mathbf{J}$ Meat Sci. $1: 30-33$.

Chidanandaiah Keshri, RC., Sanyal, MK., Kotwal, SK., and Sudhan, NA. 2005. Quality changes in enrobed/coated products during storage. Indian Food Ind. 24(1):57-61. 
Cremer, ML and Pizzimenti, KV. 1992. Effects of packaging, equipment, and storage time on energy used for reheating beef stew. J Am Diet Assoc. 92(8):954-958.

Cunniff, P. 1995. Official methods of analysis. Assoc Off Anal Chem (AOAC) 16th ed Arlington, Virginia, USA

Das, H and Jayaraman, S. 2003. A study on quality and stability of convenience dehydrated chicken pulav. J food Sci Technol. 40(1):97-101.

Das, H and Radhakrishna, K. 2001. Preservation of mutton as ready-to-eat curry by hurdle technology. J food Sci Technol. 38(3):287-289.

Devi, SM., Balachandar, V, Lee, SI and Kim IH. 2014. An outline of meat consumption in the Indian population-A pilot review. Korean J food Sci Anim Resour. 34(4):507.

Girish, PS., Nath, L., Thomas, R., Rajkumar, V and Alam, T. 2018. Development of Shelf Stable Ready-to-Eat Pork Curry Using Retort Processing Technology. J Packag Technol Res .2(1):61-66.

Keshri, RC., Sharma, N., Sharma, BD and Padda, GS. 1988. Studies on preparation and evaluation of samosa using chicken. Cherion. 17(2):75-78.

Koo, BY., Park, SJ., Byeon, YR., Son, SH. 1993. Heat penetration characteristics and keeping quality of retort pouched curry. Korean J Food Sci Technol. 25(1):63-68.

Kurian, Y., Nayar, R., Pavan, M., Rajagopal, K,. and Sunanda C. 2016. Development and quality evaluation of novel chicken cutlet incorporated with elephant foot yam (Amorphophallus paeoniifolius). Indian J Nat Sci. 7(37):11298-11306.

Laranjo, M., Talon, R., Laukova, A., Fraqueza, M.J and Elias, M. 2017. Traditional meat products: improvement of quality and safety. J Food Qual. p. 2
Lavanya, MN., Kumar, R., Saikiran, K., and Bhosale YK. 2016. Development of retort pouch processed ready to eat (RTE) Mutton Kheema Biryani. History. 23(77):11-25.

Lyon, BG and Klose, AA. 1981. Effect of heat processing in cans and retort pouches on sensory properties of fowl meat. J Food Sci. 46(1):227-233

Mathur, VK., Siddhaiah, CH., Bhatia, BS and Vijayaraghavan, PK. 1973. Canning of conventional Indian meals for Defence requirements. Indian Food Pack. 27(2):46-51.

Mendiratta, SK., Geeta, C., Anjaneyulu, ASR., Kondaiah, $\mathrm{N}$ and Keshri RC. 2005. Preparation of enrobed pork chunks. J Food Sci Technol. 42(3):220223.

Mir, SA, Masoodi, FA and Raja, J. 2017. Influence of natural antioxidants on microbial load, lipid oxidation and sensorial quality of rista-A traditional meat product of India. Food Biosci 20:79-87.

Modi, VK., Sachindra, NM., Sathisha, AD., Mahendrakar, NS., and Narasimha Rao D. 2006. Changes in quality of chicken curry during frozen storage. $\mathrm{J}$ muscle foods. 17(2):141-154.

Muthukumar, M, Naveena, BM., Sen AR and Babji, Y. 2015. XXIII Annual conference \& National Symposium of Indian Poultry Science Association. In: XXIII Annual conference \& National Symposium on Indian Poultry production in changed global scenario: Challenges and Opportunities. Indian Poultry Science Association, p 160.

Paulose C, Nayar R, Rajagopal K, James L., Sunanda, C and Magna Thomas. 2018. Effect of clove bud oleoresin and turmeric oleoresin on quality of functional chicken cutlet. Indian $\mathrm{J}$ Nat Sci. 9(51):15567-15572.

Rathod, K.S., Pawade, A.A., Ambadkar, R.K., 
2019. Storage Stability of Chicken Momo at Super Chilling Temperature. Int. J. Curr. Microbiol. Appl. Sci., 7 (12), 3154-3164.

Rajkumar, V., Dushyanthan, K., and Das, AK. 2010. Retort pouch processing of Chettinad style goat meat curry-a heritage meat product. J Food Sci Technol 47(4):372-379.

Rasheed, MA., Sudhakar, RK., Kondal, RK., and Rao, L. 2007. Effect of meat and extender ratio on quality of haleem during storage. J Food Sci Technol 44(4):430-432.

Sharma, BD., Padda, GS., Keshri, RC., and Sharma, N. 1988. Acceptability studies of different stuff binders in chevon samosas. Indian J Sci Technol 1:32-36

Singh, PK., Kumar, S, Kumar, P and Bhat,
ZF. 2014. Effect of mincing on the quality characteristics of chevon cutlets. J Anim Res. 4(2):193-200.

Singh, T., Chatli, MK., Kumar, P., Mehta, N., and Malav, OP. 2015. Effect of different cooking methods on the quality attributes of chicken meat cutlets. J Anim Res. 5(3):547-554.

Sofia, PK., Prasad, R., Vijay, VK., Srivastava, AK. 2007. Evaluation of antibacterial activity of Indian spices against common foodborne pathogens. Int $\mathrm{J}$ food Sci Technol. 42(8):910-915.

Thornton, PK. 2010. Livestock production: recent trends, future prospects. Philos Trans R Soc B Biol Sci 365(1554):2853-2867.

\section{How to cite this article:}

Renuka Nayar, Kavitha Rajagopal, Solomon Rajkumar and Magna Thomas. 2021. Documentation and Evaluation of Traditional Meat Products of North Malabar. Int.J.Curr.Microbiol.App.Sci. 10(01): 1184-1194. doi: https://doi.org/10.20546/ijcmas.2021.1001.142 